\title{
Impact of Ownership Structure on Bank Risk Taking: A Comparative Analysis of Conventional Banks and Islamic Banks of Pakistan
}

\author{
ARIF HUSSAIN \\ Assistant Professor, Institute of Business Studies and Leadership \\ Abdul Wali Khan University, Mardan \\ arifhussain@awkum.edu.pk \\ DR. ALAM REHMAN \\ Assistant Professor, National University of Modern Languages, Islamabad \\ alamrahmannuml@numl.edu.pk \\ AQSA SIDDIQUE \\ Assistant Professor, University of Peshawar \\ aqsaqcc@uop.edu.pk \\ HASEEB UR REHMAN \\ Assistant Professor, University of Science and Technology, Bannu \\ haseebbaboo@yahoo.com
}

\begin{abstract}
This study is about the impact of ownership structure on bank risk taking with comparison between conventional banks and Islamic banks of Pakistan. Z-Score and SDROA are used as risk taking variables. While managerial ownership, institutional ownership, foreign ownership and block holders were taken as proxies for ownership structure. Ten private commercial banks and four Islamic banks were randomly selected and data have been collected from annual reports of these banks from 2010 to 2016. The result suggested that all the proxies of ownership structure i.e. managerial ownership, institutional ownership, foreign ownership and block holders have significant positive impact on Z-Score. On the other hand using SDROA as proxy for risk taking the proxies of managerial ownership has significant positive impact on SDROA and institutional ownership has significant negative impact on SDROA of banks in Pakistan. On the other hand foreign ownership and block holders have insignificant impact on SDROA. The result of BankID is significant which shows that ownership structure has significant impact on bank risk taking in conventional banks while in Islamic banks ownership structure doesn't have any significant impact on bank risk.
\end{abstract}

Key Words: Ownership structure, Bank Risk, Commercial Banks, Islamic Banks.

\section{Introduction}

Banking sector plays a very important function in the development of the country. The healthy and established strong banking system is essential for sustainable economic developments of a country. In the last few year, Pakistani banks have been facing many challenges after the third financial crisis and take strong and reasonable action to save this hard and insecure time and improved their performance. In order to defend against 
negative shocks and sustain financial stability, it is very important to recognize the factors that most influence the overall performance of banks in Pakistan. Hence, in the conventional banking system bank give a loan to people, institution and other customers. Banks charge some interest and earn money. Nowadays risk management plays a very vital role in the banking industry. Banks and other financial institutions face a lot of risk in our daily business operation such as credit or default risk, foreign currency exchange risk, interest rate fluctuation risk, liquidity risk, other types of risk which may cause a default of a banking system. Therefore, an effective risk management practice is absolutely obligatory for bank survival and success.

Iqbal and Mirakhor (2011) stated that these last three decades before the banks were only confronted with credit and marketplace risk, but now the banking business has changed over a period of time and is now exposed to many Risks due to new products that were not previously submitted. The need for risk management is considered due to the following factors and changes in the market: Firstly, the increased market volatility after the breakdown of Breton Woods's system of foreign exchange rates resulted in the instability in foreign exchange rate and interest rate. Secondly, the increased development of new products in the derivative market has raised the need for risk management system in financial institutions to control risks attached to new products.

Thirdly, the banking system is changing from a traditional lending model to fee-earning behaviour. The increased role of wealth and capital market has played a role in changing the character of intermediation by moving it from formal financial institutions towards the market directly. As a result, mutual funds have taken an increased share in the market from traditional banks. Fourthly, it's difficult for small banks to survive in the market due to increased cost associated with managing risks and doing business. As a result, many mergers have taken place since the 1990s. Lastly there have been a number of financial crises from third globe debt crisis (1980) to East Asian crisis (1990) which have given rise to the need of having coordinated regulations and supervisions for the whole financial system with a focus on risk management and capital requirements globally.

Risk management is becoming more and more attentive to the global financial crisis, the risk management technique and tools used by the commercial and Islamic banks are clearly appropriate an vital issue for debate.

Market unrest has reinforced the need to make another study of the monetary system of developed and emerging countries. There is also a need to recognize the causes that led to the economic disaster. After the financial disasters, it was noted that the inability of many financial firms was due to poor risk supervision techniques, deficiencies in risk models, measurement techniques and mitigation. Moreover, the entire financial structure is based on greed and a lack of morality (Chapra, 2009). Here the question is that how the different types of ownership effect the two different type of banking operations. The objectives of this study are to find out the impact of Institutional, Managerial, and Foreign and Block holder ownership on banks risk-taking behavior. Also the impact of various types of ownership structure on bank risk taking in conventional banks and Islamic banks in Pakistan will also be asserted.

\section{Literature Review}

A review of the theoretical and empirical literature reveals that various studies made an attempt to analyze the determinants of bank risk-taking. Consistent with agency theory, 
mostly the conflict occurs between shareholders and managers (Jensen and Meckling, 1976). Theory suggests that manager's are risk-averse to safeguard their position and private advantages whereas the different type of ownership structure with a portfolio has incentives to extend bank risk once assembling funds bondholders and depositors (Galai \& Masulis, 1998). However, the agency drawback could also be alleviated in companies with targeted possession structure, as dominant shareholders have robust incentives to observe managers, and even replace them with the case of poor performance (Franks, Mayer and Amp, 2001). So risk-taking is anticipated to be a lot of pronounced in companies with targeted possession than in companies with spread possession structure. Many studies (e.g. Haw et al., 2010 \& Laeven and Levine, 2009) showed that targeted possession management is related to larger risk. Family corporations may avoid risktaking as a result of their intention is to shift an organization to consequent generation (Anderson, Mansi \& amp Reeb, 2003).

However, different researchers (Laeven, 1999 and Anderson et al., 2003) found that family companies area unit considerably less diversified, and thus riskier than non-family companies. Additionally, to the distinction between family and non-family closely-held companies, different aspects are well established within the literature regarding Government-owned and privately Institutional-owned companies. Iannotta, Nocera and Sironi (2007) selected a sample of 181 banks from fifteen EU region. They noticed that government owned financial institutions have a poor quality of loan as compared to other financial institutions like personal and mutual-owned banks according to performance and risk. Whereas public banks have higher risk and lower loan quality as compared to mutual banks. According to Laeven (1999) foreign banks are riskier than government owned banks, institutional-owned and family -owned banks. Many studies (Gonzalez, 2005 and Laeven and Levine, 2009 ) found that deposit insurance, activity restrictions, capital regulation and shareholders' protection have an effect on the flexibility of bank owners to address risk. As an example, deposit insurance intensifies the flexibility and incentives of stockholders to extend risk (Keeley, 1990 and Merton, 1977).

Chun et al. (2011) documented the impact of managerial ownership on risk taking of Japanese and Korean banks. They concluded that enhanced managerial ownership increases the risk of Japanese banks while it does not add to the total risk of banks in Korea. Chou and Lin (2011) conducted a study to examine the effect of various types of ownership on risk taking of banks in Taiwan. They concluded that banks having higher government ownership and managerial ownership have higher risk while banks having higher government ownership have lower risk. Ianoatta et al. (2012) studied a large sample of European banks and asserted that government ownership in banks is positively related with operation risk and negatively related with default risk. Garcia-Marco and Robes-Fernandez (2008) concluded about Spanish banks that Government banks assume higher risk. Shleifer and Vishny (1986) suggested that external shareholders in the form of block holders and institutional shareholders having extensive voting rights significantly effects bank risking aptitude.

\section{Hypotheses}

$\mathrm{H}_{1}$ : There is a positive relationship between institutional ownership and bank risk taking $\mathrm{H}_{2}$ : There is a positive relationship between managerial ownership and bank risk taking $\mathrm{H}_{3}$ : There is a positive relationship between government ownership and bank risk taking 
$\mathrm{H}_{4}$ : There is a positive relationship between block holders ownership and bank risk taking

3. Research Methodology

3.1 Population and sample

The population of this study is based on all commercial banks listed in Pakistan. There are twenty two conventional commercial banks and four Islamic banks are listed in Pakistan. Ten conventional commercial banks were randomly selected from twenty two conventional banks and all four listed Islamic banks in Pakistan are selected for this study. Data were collected from the annual reports of concerned banks from 2010 to 2016.

Table 1: Definition of Variables

\begin{tabular}{ll}
\hline Variables & Measurement \\
\hline Z-Score & $\begin{array}{l}\text { Indicator of insolvency risk, measured as the mean } \\
\text { of return on assets plus the capital asset ratio (equity } \\
\text { capital/total assets) divided by the standard } \\
\text { deviation of asset returns. }\end{array}$ \\
$\begin{array}{l}\text { Standard deviation of net income of total assets } \\
\text { Institutional Ownership (INO) }\end{array}$ & $\begin{array}{l}\text { Proportion of equity held by financial and non- } \\
\text { financial company. } \\
\text { Proportion of equity held by board of directors and } \\
\text { other managerial persons. } \\
\text { Managerial Ownership (MNO) }\end{array}$ \\
Foreign Ownership (FRO) & $\begin{array}{l}\text { Equity percentage participation by foreign } \\
\text { institutions and individual. } \\
\text { Equity percentage participation by the largest } \\
\text { shareholder of the bank. }\end{array}$ \\
Block Holder (BH) & $\begin{array}{l}\text { Log of total assets } \\
\text { Firm Size (FS) }\end{array}$ \\
Bank Dummy (BD) &
\end{tabular}

\subsection{Regression Equations}

Z-score $=\alpha_{0}+\alpha_{1} \mathrm{MNO}+\alpha_{2} \mathrm{INO}+\alpha_{3} \mathrm{FRO}+\alpha_{4} \mathrm{BHD}+\alpha_{5} \mathrm{FS}+\alpha_{6}$ bankid $+\mu$

$\mathrm{SDROA}=\beta_{0}+\beta_{1} \mathrm{MNO}+\beta_{2} \mathrm{INO}+\beta_{3} \mathrm{FRO}+\beta_{4} \mathrm{BHD}+\beta_{5} \mathrm{FS}+\beta_{6}$ bankid $+\mu$

\section{Data Analysis}

\subsection{Descriptive Statistics}

Table 2: Descriptive Statistics

\begin{tabular}{lllll}
\hline Variable & Mean & Std. Dev & Min & Max \\
\hline Z-score & 33.29425 & 21.6467 & 1.683387 & 98.60623 \\
SDROA & 0.145974 & 1.03131 & 0.000843 & 8.198762 \\
MNO & 0.094374 & 0.15692 & 0.002452 & 0.75521 \\
INO & 0.435286 & 0.33781 & 0.003133 & 0.9709 \\
FRO & 0.796127 & 3.49727 & 0.012341 & 27.75 \\
BHD & 0.604179 & 0.29474 & 0.043124 & 0.97 \\
FS & 239085.5 & 1897573 & 10.71522 & 1.51 \\
\hline
\end{tabular}

The above table shows the descriptive statistic of all given variables. The table shows their standard deviation and means, and minimum \& maximum values. The dependent variable $\mathrm{Z}$-score mean is 33.29425.It has a maximum value of $98.60623 \&$ a minimum value of, 1.683387; the SD for Z-score is 21.64671. The second dependent variable 
SDROA mean is 0.1459746 .It has a maximum value o $8.198762 \&$ a minimum value of 0.000843 . The SD for SDROA is 1.031315. The independent variable managerial ownership mean is 0.0943745 .It has a maximum value of $0.75521 \&$ a minimum value of 0 the SD of managerial ownership is 0.15692 . The second independent variable institutional ownership means is 0.4352865 .It has a maximum value of, 0.9709 \& a minimum value of 0.003133 the SD of institutional ownership is 0.3378154 . The third independent variable foreign ownership means is 0.7961275.It has a maximum value of, $27.75 \&$ a minimum value of 0.012341 the SD of foreign ownership is 3.497274 . The fourth independent variable block holder means is 0.604179 .It has a maximum value of $0.97 \&$ a minimum value of 0.043124 the SD value of block holder is 0.2947424 . The control variable firm size mean is 239085 .5. It has a maximum value of, 1.51 and a minimum value of 10.71522 the SD of firm size is 1897573 .

\subsection{Correlation Analysis}

The correlation measures the degree of association between different variables under consideration.

Table 3: Correlation Analysis

\begin{tabular}{llllllll}
\hline & Z- & SDROA & MNO & INO & FRO & BHD & FS \\
& SCORE & & & & & & \\
\hline Z-SCORE & 1.0000 & & & & & & \\
SDROA & -0.1004 & 1.0000 & & & & & \\
MNO & 0.2388 & 0.0044 & 1.0000 & & & & \\
INO & -0.4130 & 0.0115 & 0.0312 & 1.0000 & & & \\
FRO & 0.0330 & -0.0186 & -0.0065 & 0.0387 & 1.0000 & & \\
BHD & -0.2737 & 0.1586 & -0.0846 & 0.5352 & -0.0689 & 1.0000 & \\
FS & -0.0695 & -0.0127 & -0.0772 & -0.1672 & -0.0075 & -0.2627 & 1.0000 \\
\hline
\end{tabular}

The above table shows correlation among variables. It shows that MNO has a positive (0.2388) relationship with Z-score and also show positive (0.0044) relation with SDROA.INO show negative (-0.4130) relationship with Z- score and also show positive (0.0115) relationship with SDROA. FRO show positive (0.0330) relationship with Zscore but negative relationship (-0.186) with SDROA. BHD and FS show negative (0.2737), (-0.0695) relationship respectively with Z-Score while BHD has a positive relationship (0.1586) with SDROA. FS has negative (-0.0127) relationship with SDROA. $\mathrm{MNO}$ and FRO has positive correlation with Z-score.

\subsection{Regression Analysis}

Table 4: Regression Analysis

\begin{tabular}{lllll}
\hline Variables & Coff. & SD error & T- value & P-value \\
\hline MNO & 11.847 & 16.07271 & 4.32 & 0.007 \\
INO & 6.527894 & 10.08265 & 5.13 & 0.007 \\
FRO & 0.284629 & .6887376 & 3.98 & 0.0001 \\
BHD & 21.39076 & 10.84376 & 1.97 & 0.034 \\
FS & 1.2 & 1.27 & 0.80 & .426 \\
BANK ID & 20.25597 & 6.077404 & 3.33 & .002 \\
F-Statistic & 4.80 & & & \\
R-Square & 0.3800 & & & \\
\hline
\end{tabular}

Dependent Variable $=$ Z-Score 
Result of regression analysis using Z-Score as dependent variable is given in table 4. It shows that value of F-Statistics is significant so the model is fit as a whole while coefficient of determination is $38 \%$ which shows the explanatory power of independent variables to explain the dependent variables. All the independent variables i.e. managerial ownership, institutional ownership, foreign ownership and government ownership have significant negative impact on default risk i.e. the Z-Score. It shows that for commercial banks in Pakistan higher concentration of ownership enhances bank risk. These results are according to the studies Chun et al. (2011), Ianoatta et al. (2012), Chou and Lin (2011). These studies also recommend that higher managerial ownership, higher institutional ownership, single block holders, and higher government ownership increases bank risk. The result of BankID is significant which shows that ownership structure has significant impact on bank risk taking in conventional banks while in Islamic banks ownership structure doesn't have any significant impact on bank risk.

Table 5: Regression Analysis

\begin{tabular}{lllll}
\hline Variables & Coeff. & SD error & T- value & P-value \\
\hline MNO & .0616271 & .9548703 & 2.511 & 0.008 \\
INO & -0.1966975 & 0.599004 & -3.42 & 0.001 \\
FRO & -0.003359 & 0.0409175 & -0.08 & 0.935 \\
BHD & 0.6927832 & 0.6442216 & 1.08 & 0.287 \\
FS & 2.05 & 7.56 & 0.27 & 0.788 \\
BANK ID & 0.094 & 0.124 & 0.754 & 0.910 \\
R-Square & $33.65 \%$ & & & \\
F-Statistics & 5.64 & & & \\
\hline
\end{tabular}

Dependent Variable $=$ SDROA

Table 5 shows impact of various ownership structure proxies by using standard deviation of return on assets (SDROA) as dependent variable. The result shows a significant value of F-Statistics which shows fitness of model as a whole while coefficient of determination is $33.65 \%$ and shows the explanatory power of ownership proxies to explain bank risk taking. The result further shows that managerial ownership has significant positive impact on bank risk. Institutional ownership has significant negative impact on bank risk. On the other hand foreign ownership and block holders ownership have insignificant positive impact on bank risk. The result of BankID is significant which shows that ownership structure has significant impact on bank risk taking in conventional banks while in Islamic banks ownership structure doesn't have any significant impact on bank risk.

\section{Conclusion and Recommendation}

This study is about the impact of ownership structure on bank risk taking with comparison between conventional banks and Islamic banks of Pakistan. Z-Score and SDROA are used as risk taking variables. While managerial ownership, institutional ownership, foreign ownership and block holders were taken as proxies for ownership structure. The result suggested that all the proxies of ownership structure i.e. managerial ownership, institutional ownership, foreign ownership and block holders have significant positive impact on Z-Score. These results are according to the studies of Chun et al. (2011), Ianoatta et al. (2012), Chou and Lin (2011). On the other hand using SDROA as proxy for risk taking the proxies of managerial ownership has significant positive impact 
on SDROA and institutional ownership has significant negative impact on SDROA of banks in Pakistan. On the other hand foreign ownership and block holders have insignificant impact on SDROA. The result of Bank ID is significant which shows that ownership structure has significant impact on bank risk taking in conventional banks while in Islamic banks ownership structure doesn't have any significant impact on bank risk. This research would add to the academia and the industry and future researchers can take help from this research and can further add up to the value by using other risk measures like beta, value at risk, interest rate risk and operational risk. A further area of research could use pool data and multiple regression models with more detailed data results to predict some strong policy for the banking industry in Pakistan. Another further recommendation of the research is to conduct an individual study on domestic and foreign banks to evaluate the ownership structure more in-depth such as dividing the ownership into family groups of non-family groups. This may provide the inside story to show the impact on financial performance of the banks.

\section{References}

Anderson, R.C., \& Fraser, D.R. (2000). Corporate control, bank risk-taking, and the health of banking industry. Journal of Banking and Finance, 4, 1383-1398.

Chou S. \& Lin, F. (2011). Bank's risk-taking and ownership structure - evidence for economics in transition stage, Vol.43(12), p. 1551-1564

Chun, S.E, Nagano, M., \& Lee, M. ( 2011). Ownership structure and risk-taking behaviour: Evidence from banks in Korea and Japan. Asian Economic Journal, Vol. 25( 2) , p. 151-175.

.Garcia-Marco, T., \& Robles-Fernández, M. D., (2008). Risk-taking behaviour and ownership in the banking industry: The Spanish evidence. Journal of Economics and Business, Vol. 60(4), p332- 354.

Haw, I.M., Ho, S., Hu, B., \& Wu, D. (2010). Concentrated control, institutions, and banking sector: An internal AQZ national study. Journal of Banking and Finance, 34, 485-497

Iannotta, G., Nocera, G., \& Sironi, A., (2012). The impact of government ownership on bank risk. Journal of Financial Intermediation, Vol.22(2), p. 152-178

Laeven, L., \& Levine, R. (2009). Bank governance, regulation and risk taking. Journal of Financial Economics,93, 259-275

.Shleifer, A., \& Vishny, R. (1986). Large shareholders and corporate control. The Journal of Polictical Economy, 94, 461-488. 